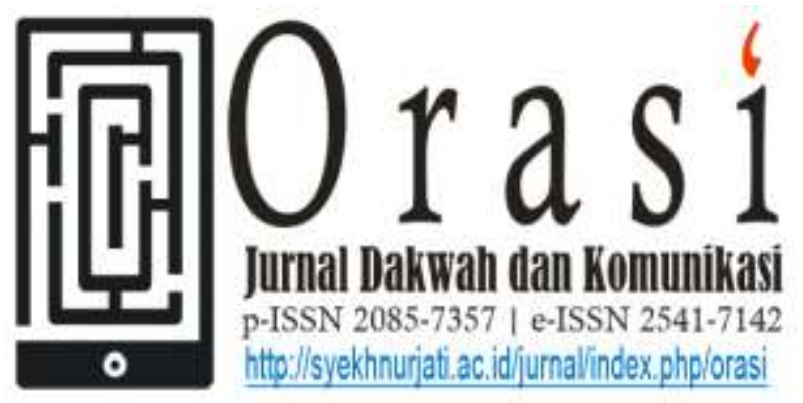

Volume 11 No. 1 Juli 2020

\title{
ORIENTASI PENGEMBANGAN DAKWAH MELALUI SISTEM KOMUNIKASI (MEDIA MASSA)
}

\section{ORIENTATION OF PROPAGATION DA'WAH THROUGH THE COMMUNICTION SYSTEM (MASS MEDIA)}

\author{
Asriyanti Rosmalina, a), dan Nasrudin Abdul Matin ${ }^{2, b)}$ \\ ${ }^{1,2}$ Jurusan Komunikasi dan Penyiaran Islam, IAIN Syekh Nurjati Cirebon \\ a) e-mail: asriyantirosmalina@gmail.com \\ b)e-mail:nazmatinraikas@gmail.com
}

\begin{abstract}
ABSTRAK
Motif komunikasi dalam kegiatan keagamaan marak dilakukan dalam sisi kehidupan khususnya dalam dakwah islamiyah. Motif ini timbul akibat semakin berkembangnya arus globalisasi, teknologi informasi serta semakin meningkatnya kebutuhan hidup manusia yang harus berkiblat kedalam perkembangan zaman. Sisi dakwah dalam kacamata komunikasi merupakan sebuah aktifitas menerangkan, menyampaikan pesan ajaran islam secara al-qur'an dan hadist serta pertimbangan para ulama sehingga orang yang mendapatkan pesan dan informasi dapat terpengaruh dan selanjutnya dapat merubah perilakunya secara ajaran islam. Signifikasi dakwah pun digunakan oleh masyarakat di luar islam untuk suatu alat perjuangan dengan adanya media massa tersebut sebagai perantara penyampaian pesan kepada khalayak banyak. Keberadaan media massa ini sangat berpengaruh kepada masyarakat, karena dari media massa akan membentuk suatu opini bahkan mengubah perilaku masyarakatnya. Hadirnya media massa ini membawa nilai positif dan negatif. Keberadaan media massa ditengah masyarakat sangat dipandang urgen bahkan mampu mempengaruhi pola pikir serta perilaku masyrakat, ketika sebuah peristiwa diorientasikan media yang akan menjadi sebuah tayangan bermuatan dakwah dan diakses publik yang meliputi umat islam selaku mad'unya, tentu hal tersebut menjadi harapan yang kuat sebagai pengembangan dakwah melalui media massa dengan orientasi yang benar, karena media massa dapat memberikan kesan ataupun efek yang khusus bagi individu, kelompok atau lingkungan tertentu. Secara gambaran personal (individu) manusia sendiri bahwa media massa dapat memberi pengaruh pada tiga level (efek kognitif, afektif dan konasi). Media menyadari bahwa dakwah merupakan kebutuhan masyarakat termasuk informasi atau pemberitaan tentang agama. Dalam konteks ini media harus mampu mengemas dalam bentuk
\end{abstract}


informasi atau pemberitaan yang mengandung pesan-pesan keagamaan karena melalui proses ini, orientasi pengembangan dakwah akan tertuju dengan baik.

Kata Kunci: Media, Orientasi, Pengembangan Dakwah

\begin{abstract}
The motive for communication in religious activities is widely done in most aspects of life, especially in Islamic da'wah. This motive arose due to the growing development of globalization, information technology, and the increasing needs of human life that must be oriented into the times. Da'wah in the eye of communication is an activity explaining and conveying the message of Islamic teachings in the Qur'an and hadith as well as the consideration of the ulama so that people who get the message and information can be affected and can then change their behavior into that of Islamic teachings. The significance of da'wah is also used by non-Islamic community for a means of struggle with the presence of mass media as an intermediary to deliver messages to the public. The existence of mass media is very influential to the community because mass media has the power to form an opinion even change the behavior of the community. The presence of mass media brings positive and negative values. The existence of mass media in the midst of the community is seen as urgent and even able to influence the mindset and behavior of the community as an event is oriented by the media which will become a missionary and publicly accessible program including Muslims as the mad'u. This certainly is a strong hope as the propagation of da'wah through mass media with the correct orientation because mass media can give an impression or a special effect for certain individuals, groups, or environments. Affecting individuals, mass media can influence at three levels (cognitive, affective, and conational). From the media, it is realized that da'wah, which includes knowledge and news about Islam, is a need of the community. In this context, media must be able to package da'wah in the form of information or news that contains religious messages because through this process the orientation of da'wah propagation will be well directed.
\end{abstract}

Keywords: Media, Orientation, Propagation of Da'wah

\section{Pendahuluan}

Hadirnya media massa ditengah
ketidak canggungan zaman, sangat berpengaruh terhadap kehidupan masyarakat, karena media massa mampu membentuk opini bahkan perilaku masyarakat sehingga bisa menimbulkan nilai positif dan nilai negatif. Penekanan terhadap aktivitas perlu diarahkan dalam membentuk perilaku yang baik bagi masyarakat sehingga media bisa memberikan kontribusi melalui pemberitaan pengembangan dakwah dalam masyarakat.
Perkembangan sosial terhadap perilaku masyarakat sangat ditentukan oleh orientasi media yang dapat mempengaruhi suatu informasi yang dominan didapatkannya, berikut dari berbagai media yang diterimanya. Dari transformasi informasi tersebut dengan era sekarang ini sangat bebas terbuka dalam mengakses di media sesuai dengan keinginannya, sehingga akan menimbulkan perubahan yang drastis terhadap perilaku masyarakat. Perubahan yang tampak ini sangat lebih berdampak dari aspek perilaku keagamaan disamping aspek lainnya. 
Perubahan perilaku keagamaan akibat dari transformasi informasi media, yang terindikasi dari moralitas masyarakatnya yang terkadang mengabaikan nila-nilai agama.

Maka kehadiran media mesti direspon agar memberi dampak positif terhadap perilaku keagamaan masyarakat sehingga mampu mempertahankan nila-nilai yang selama ini dianut masyarakat. Media hadir membawa nilai negatif terhadap perilaku keagamaan, jika dilihat dari sikap masyarakat yang mengakses informasi tidak selektif tersebut, khususnya bagi kalangan anak-anak dan remaja.

Namun disisi lain, media justru dipercaya memberi kontrubusi yang positif terhadap perilaku masyarakat termasuk bidang keagamaan, hal ini tampak dari berbagai media yang tersedia beragam acara, kegiatan atau kemasan suatu pesan terkait keagamaan yang disajikan langsung di media, seperti halnya pada akun instragam vlog video nunuzo yang menginspirasikan kaum muda milineal, dan banyak macam lainnya yang dikemas dalam video di youtube, dengan tayangan dari kalangan atas, dan menengah bawah.

Kegiatan dakwah kini kian meroket dengan ditandai tingginya respon sejumlah media yang digunakan sebagai suatu kebutuhan oleh manusia itu sendiri. Dalam perkembangannya, media mampu melakukan konstruksi sosial dalam bentuk opini publik terhadap realita ditengah-tengah masyarakat. Sebagai dasar mengukurnya nilai positif dan negatif suatu media terhadap perilaku masyarakat perlu disertai dengan kajian akademik sehingga memiliki kualifikasi keilmiahan, dipandang baik dan buruk dampak media sangat tergantung dari perspektif yang digunakan.

Karakteristik masyarakat yang memiliki rasa ingin tahu dan keinginan mencoba segala sesuatu yang dilihatnya menjadi faktor determinan yang menjadikan acara televisi dan media lainnya membawa dampak negatif. Dari berbagai pandangan sementara itu media justru efektif dijadikan sebagai media dakwah untuk menyebarkan informasi-informasi keagamaan sehingga pesan-pesan dakwahnya dapat dicerna dan diamalkan kepada masyarakat. Persoalan yang muncul kemudian ialah terhadap adanya media sebagai media dakwahnya atau justru kehadiran media menjadi tantangan dakwah.

Aktivitas dakwah diorientasikan untuk transformasi personal dan kolektif umat ke arah yang lebih baik serta meminimalisir kemunkaran. Idealistis dakwah tersebut behadapan dengan realita kehidupan masyarakat yang lebih mengarah pada aspek pragmatisme ditengah menjamurnya budaya pop/melinial style dan cenderung mengabaikan agama. Hal ini tidak terlepas dari kontribusi media pada sisi negatifnya yang mampu mempengaruhi dan merubah pola pikir hingga perilaku masyarakat yang paradoks dengan nilai-nilai budaya dan agama. Aktivitas dakwah menjadi suatu kemutlakan dengan melakukan inovasi-inovasi dalam menjaga eksistensi agama secara berkesinambungan, islam dalam hal ini sebagai agama dakwah (tercermin dalam sejarah nabi yang membela dan mensyiarkan islam dengan berdakwah) 
menjadikan kegiatan tersebut sebagai perekat terpeliharanya nilai-nilai islam. Proses pengiriman pesan-pesan dakwah dari seorang da'i kehadapan mad'unya yang menjadi sasaran dakwah dalam bingkai amar ma'ruf nahi munkar.

Potret perkembangan dakwah di zaman sekarang ini, dihadapkan pada kompleksitas persoalan umat. Karenanya, para da'i harus berkiprah secara profesional bertujuan untuk memberikan jalan penjelasan agama bagi umatnya dalam menentukan atau mengenai persoalan-persoalan kehidupan agar tetap istiqomah, dalam menjalankan nilai-nilai agama yang dianutnya. Kegiatan dakwah diyakini membawa pengaruh terhadap kemajuan islam. Sebaliknya, aktivitas dakwah yang lemah akan berdampak pada kemunduran islam.

Berdakwah melalui media dengan kualifikasi konten hiburan tersebut merupakan tugas yang mulia dengan harapan mereka para pelaku media hiburan dapat memperjuangkan kebenaran dengan menegakkan amar ma'ruf dan nahi munkar dalam skala lebih luas melalui media tanpa membiasakan makna dakwah tersebut. Berbagai persoalan dari pola dan intensitas perilaku keagamaan masyarakat tidak terlepas dari besarnya pengaruh media massa tersebut. Hal ini menarik untuk dicermati dalam paradigma akademik, untuk bisa mengetahui orientasi pengembangan dakwah pada zaman sekarang ini dengan marak dan meningkatnya pengguna media massa begitupun dengan media sosial sebagai bentuk jalan penyampaian pesan dakwahnya.

\section{Metodologi Penelitian}

Metode penelitian ini merupakan metode kualitatif, dimana jenis penelitian yang menghasilkan penemuan-penemuan yang tidak dapat dicapai dengan menggunakan prosedur statistik atau cara kuantifikasi lainnya. Metode deskriptif dengan pendekatan kualitatif menjelaskan dan menggambarkan fenomenafenomena yang terjadi.

Metode penelitian kualitatif adalah metode penelitian yang berlandaskan pada filsafat postpositivisme atau interpretif, digunakan untuk meneliti pada kondisi obyek yang alamiah, dimana peneliti adalah sebagai instrumen kunci, teknik pengumpulan data dilakukan secara trianggulasi (gabungan obeservasi, wawancara, dokumentasi), data yang diperoleh cenderung data kualitatif, analisis data bersifat induktif/kualitatif, dan hasil penelitian kualittatif bersifat untuk memahami makna, memahami keunikan, dan mengkonstruksikan fenomena (Sugiyono 2018).

Untuk menganalisis data, digunakan metode analisis deskriftif kualitatif. Sesuai dengan pendekatan yang digunakan ialah kualitatif deskriptif sehingga data yang berhasil dikumpulkan tidak menggunakan uji statistik, melainkan non statistik sesuai dengan peneliti yang bersifat kualitatif.

Denzin dan Lincoln menyatakan bahwa peneliti kualitatif adalah pada anlisis data kualitatif, kata-kata dibangun dari hasil pengamatan terhadap data yang dibutuhkan untuk mendeskripsikan dan dirangkum (Patilima 2005). 
Penulis menggunakan teknik analisis data interaktif Miles dan Huberman, dimana reduksi data, penyajian data dan verifikasi atau penarik kesimpulan disatu padukan dengan menghasilkan sebuah data yang dibutuhkan peneliti.

\section{Hasil dan Pembahasan}

\subsection{Dakwah dan Komunikasi (Media Massa)}

Dalam bentuk usaha seseorang untuk menelaah orientasi masalah-masalah objektivitas, metodologi, sumber, serta validasi pengetahuan secara mendalam dengan menggunakan dakwah sebagai suatu subjek pembahasan (Suisyanto 2006), kini kegiatan dakwah menjadi semarak dengan merambah ke dunia media massa yang terukur dengan tujuan yang jelas. dalam perkembangannya, media mampu memberikan orientasi terhadap kemajuan dakwah pada opini yang ada dalam keadaan realitas di tengah-tengah masyarakat.

Dalam pengamatan Elvinaro Ardianto dkk, pada kutipan DeVito (1984) dalam proses komunikasi massa, orientasi internasional biasanya dilakukan oleh komunikan terhadap komunikator, bukan sebaliknya. Cara dalam komunkasi sebagai orientasinya ialah dengan ekstensionalitas yang merupakan cara dengan memberikan perhatian utama kita pada manusia, benda atau kejadian-kejadian di dunia ini sesuai dengan apa yang kita lihat (Ardianto, Komala, dan Karlinah 2012).

Sementara dakwah senantiasa bersentuhan dengan realitas dalam masyarakat tertentu. Secara historis, interaksi islam dengan realitas sosio-kultural terdapat dua kemungkinan. Pertama, dakwah islam mampu memberikan pengaruh terhadap lingkungan sehingga terbentuknya realitas sosial yang baru. Kedua, dakwah islam terpengaruh oleh perubahan masyarakat dalam arti eksistensi corak dan arahnya. Ini berarti bahwa aktualitas dakwah ditentukan oleh sistem sosio-kultural. Jika kemungkinan kedua ini yang terjadi maka dakwah akan bersifat statis atau terdapat dinamika dengan kadar hampir tidak berarti bagi perubahan sosio-kultural (Syobah 2013).

Dalam aplikasi penyampaian dakwah, seorang dai sebagai subjek dakwah memerlukan seperangkat pengetahuan dan kecakapan dalam hal metode. Dengan mengetahui metode maka dai mampu memahami dan menyampaikan materi kepada objek dakwah yang sedang dihadapinya dengan harapan bahwa pesan yang disampaikan dai diterima dan mampu dipahami pula oleh mad'u.

Makna dakwah secara praktis berarti mengajak atau menyeru manusia ke jalan Allah SWT, secara kontekstual aktivitas dakwah merupakan proses melakukan perubahan situasi dan kondisi sosial masyarakat, dari kondisi sosial yang buruk menjadi lebih baik, dari situasi yang kurang mendukung menjadi situasi yang lebih kondusif.

Dikuatkan oleh pendapat Syeikh Ali Mahfuzh, dakwah merupakan proses memberikan motivasi dalam menyampaikan pesan dakwah kepada mad'u untuk membangkitkan kesadaran umat dalam kebaikan dengan bimbingan menyuruh kepada yang ma'ruf mencegah dari kemungkaran. 
Karena dakwah tidak hanya dilakukan dalam menyampaikan pesan dakwahnya saja, akan tetapi dai juga menjadi guru bagi para mad'u dalam mempelajari ajaran islam. Dai disini sangat berperan penting dalam keselamatan umat yaitu ia bertanggung jawab bukan hanya di penyampaiannya saja tetapi juga dalam mengubah pola fikir untuk membangkitkan kesadaran umat menuju kepada kebaikan (Hendra dan Saputri 2019).

Aktivitas dakwah tidak bisa terlepas dari penyampaian pesan atau informasi. Dalam bahasa dakwah disebut tabligh artinya menyampaikan. Orang yang menyampaikan pesan-pesan dakwah, berdasarkan ayat alQur'an dan al-Hadits disebut "Mubaligh". Dari konsep ini dapat dimengerti bahwa tugas pokok seorang da'i (juru dakwah) adalah mengajak dan menyampaikan pesan. Tidak ada sifat memaksa, menekan, mengintimidasi, memprovokasi apalagi melakukan teror, baik mental maupun fisik.

Tugas dakwah yang spesifik ini memberikan arah agar para juru dakwah melanjutkan misi utama Nabi Muhammad SAW. Dalam berdakwah. Pertama, menjadi saksi (syaahidan) atas kebenaran ajaran islam yang bersumber dari wahyu Ilahi dan dibawa oleh Rasulullah SAW, untuk disebar luaskan kepada ummat manusia. Kedua, memberikan kabar gembira (mubassyiran) yang menyenangkan hati ummat dan masyarakat, sehingga mereka merasa tentram, damai dan selamat dalam memeluk ajaran islam. Sebagaimana sering diungkapkan oleh Nabi Muhammad SAW. "Bassyiruu walaa tunaffiruu, yassiruu walaa tu'assiruu”
(Gembirakanlah mereka jangan dibikin cemas, permudah jangan mempersusah). Ketiga, memberikan peringatan (nadziiraan) agar masyarakat tidak terlena dalam dosa dan maksiat, terbuai dengan perilaku korupsi dan manipulasi. Sebelum adzab Allah datang menimpa masyarakat dan bangsa, maka para juru dakwah bertanggung jawab untuk terus meningkatkan, sesuai perintah al-qur'an " $F a$ dzakkir innamaa anta mudzakkir". Keempat, mengajak ke jalan Allah (Daa iyaan ila Allahi), jalan kebenaran dan jalan lurus "Shiraatha al- mustaqiim" atas izin Allah. Perintah ini menegaskan bahwa ajakan kita harus tulus tidak bersifat memaksa. Hakikat hidayah adalah hak Allah untuk diberikan kepada siapa yang dikehendakinya, tugas juru dakwah semata-mata mengajak. "Innaka laa tahdii man ahbabta, walaakin Allaha yahdii man yasyaaa' $u$ " (Sesungguhnya kamu tidak berhak memberikan hidayah kepada orang yang kamu sayangi, melainkan hanyalah Allah yang berhak memberikan hidayah kepada orang yang dikehendaki Nya). Kelima, tugas pokok juru dakwah adalah memberikan sinar cahaya terang (Siraajaan Muniiraan) agar masyarakat tidak sesat jalan, atau terjerumus dalam lembah penderitaan dunia dan akhirat, akibat durhaka dan maksiat. Agar dakwah bisa mencapai sasaran, maka dengan metode dan pendekatan dakwah yang tepat (Ali 2004).

Metode dakwah adalah jalan atau cara yang dipakai juru dakwah untuk menyampaikan ajaran dakwah islam. Dalam penyampaian suatu pesan dakwah, metode sangat penting perannya, karena suatu pesan walaupun baik, tetapi disampaikan melalui 
metode yang tidak tepat maka pesan bisa saja ditolak oleh mad'unya (Syobah 2013).

Kegiatan dakwah kontemporer mengharuskan pendekatan komunikasi, khususnya melalui media. Dalam mengurai relasi bahkan integrasi dakwah dan komunikasi melalui media, memberi kesadaran untuk melakukan transformasi gerakan dakwah melingkupi pengajian di masjid-masjid atau majelis ta'lim. Selain itu aktivitas dakwah bisa melalui media massa ataupun media sosial, sebab gerakan yang paradoks dengan dakwah kini berkembang pesat, dengan merambahnya dunia maya (teknologi modern seperti internet).

Untuk itu, kontekstualisasi dakwah kontemporer menjadi suatu keharusan. Hal ini sekaligus menjawab berbagai pertanyaan di atas. Artinya, dakwah tidak tepat lagi dipahami sebatas pengajian, ceramah di tempat-tempat tertentu, melainkan harus merambah pada dunia maya, internet dan alat teknologi lainnya. Selain itu, berdakwah melalui jalur dakwah juga menjadi kebutuhan, justru saatnya diintensifkan. Betapa tidak, selama ini para elit banyak melakukan penyimpangan moral, maka saatnya figur-figur yang bermoral dengan komitmen keagamaan yang kuat untuk masuk dalam kancah dakwah praktis.

Dalam konteks ini, dakwah dipahami secara lebih luas, yakni suatu proses internalisasi nilai-nilai Islam dalam kancah kehidupan, sehingga nilai-nilai tersebut dapat mewarnai perilaku masyarakat dalam tatanan kehidupan yang Islami. Dakwah adalah upaya menyampaikan nilai-nilai ajaran Islam, secara sederhana dan universal dakwah adalah menyerukan kebaikan dan mencegah kemungkaran. Nilai dakwah ini merupakan strategi untuk mengkomunikasikan ajaranajaran suci agama yang dapat diaktualisasikan dalam berbagai formulasi tergantung kondisinya, termasuk melakukan formalisasi dakwah melalui partai dakwah (Syobah 2013).

Da'i dalam komunikasi dakwah berindikasi bahwa semua peristiwa komunikasi akan melibatkan sumber sebagai pembuat atau pengirim informasi, termasuk dalam konteks dakwah. Sumber adalah pihak yang berinisiatif atau mempunyai kebutuhan untuk berkomunikasi. Sumber ini bisa disebut komunikator, pengirim atau dalam bahasa lain source, sender, dan encoder. Sementara dalam komunikasi dakwah, sumber tersebut bisa disebut dengan da'i. Dalam bentuk komunikasi antar manusia, komunikator bisa berdiri dari satu orang, bisa juga dalam bentuk kelompok.

Pada dasarnya, semua pribadi muslim berperan secara otomatis sebagai juru dakwah, artinya orang yang harus menyampaikan atau dikenal sebagai komunikator dakwah. Siapa saja yang dapat dikenal sebagai da'i atau komunikator dakwah itu dapat dikelompokan menjadi:

a. Secara umum adalah setiap muslim atau muslimah yang mukallaf (dewasa) dimana kewajiban dakwah merupakan suatu yang melekat tidak terpisahkan dari misinya sebagai penganut islam, sesuai dengan perintah; "sampaikan walau satu ayat" 
b. Secara khusus adalah mereka yang mengambil keahlian khusus (mutakhasis) dalam bidang agama islam, yang dikenal dengan panggilan ulama.

Sebagai dasar pondasi seorang komunikator (da'i) harus memiliki prinsipprinsip komunkasi islam dengan bersumber utama pada ajaran islam, yaitu Al-Qur'an dan As-Sunnah. Dari dua sumber inilah prinsipprinsip dasar komunikasi islam diambil, diantaranya ada 12 prinsip dasar : prinsip ikhlas (suatu pesan tidak berdampak positif kepada komunikan jika diterima dengan hati yang tidak ikhlas), prinsip pahala dan dosa (setiap pesan atau pernyataan yang keluar itu mengandung konsekuensi pahala atau dosa), prinsip kejujuran, prinsip kebersihan, prinsip berkata positif, prinsip paket (hati, lisan, dan perbuatan), prinsip dua telinga satu mulut, prinsip pengawasan, prinsip selektivitas dan validitas, prinsip saling memengaruhi, prinsip keseimbangan berita (keadilan), dan prinsip privasi (Hefni 2015). Keefektifan komunikasi dakwah tidak saja ditentukan oleh kemampuan berkomunikasi, tetapi juga oleh diri komunikator. Fungsi komunikator (da'i) dalam pengaturan pikiran dan perasaannya dalam bentuk pesan untuk membuat komunikan menjadi tahu dan berubah sikap, pendapat, dan perilakunya. Karena komunikan yang akan mengkaji siapa komunikator yang akan menyampaikan pesan tersebut (Ilaihi 2013).

Sarana penyampain atau sarana ini sering kali diartikan sebagai "media" yang berasal dari bahasa latin "medius" yang berarti "perantara". Secara etimologis sarana adalah segala sesuatu yang dipakai sebagai alat dalam mencapai maksud dan tujuan. Secara terminologi, media adalah alat atau sarana yang digunakan untuk menyampaikan pesan komunikator kepada khalayak.

Sebagai pembahasan tersebut pada intinya menurut Dr. Hamzah Ya'qub, yang dimaksud media dakwah adalah alat objektif yang menjadi saluran yang menghubungkan ide dengan umat, suatu elemen yang vital dan merupakan urat nadi dalam totaliteit dakwah. Dengan demikian dapat disimpulkan bahwa media dakwah yaitu segala sesuatu yang digunakan atau menjadi penunjang dalam berlangsungnya pesan dari komunikan (da'i) kepada khalayak atau dengan kata lain bahwa segala sesuatu yang dapat menjadi penunjang/alat dalam peroses dakwah yang berfungsi mengefektifkan penyampaian ide (pesan) dari komunikator (da'i) kepada komunikan (khalayak/mad'u) (Syamsuddin 2016).

Media massa sebagai bentuk atau alat penyampaian pesan dari komunikasi massa yang memiliki fungsi bagi masyarakat itu sendiri diantaranya: (1) pengawasan atau peringatan terjadi ketika media massa menginformasikan yang memiliki kegunaan atau dapat membantu khalayak dalam kehidupan sehari-hari. (2) penafsiran hampir sama dengan pengawasan tetapi dalam hal ini media massa tidak hanya memasok sebuah fakta dan data, tetapi juga memberikan penafsiran terhadap kejadian-kejadian penting. (3) pertalian, dalam hal ini media massa dapat menyatukan anggota masyarakat yang beragam sehingga membentuk linkage 
(pertalian kesepakatan) yang berdasarkan kepentingan dan keinginan yang selaras. (4) hiburan, dengan tujuan supaya khalayak tidak terlalu tegang ketika menerima suatu pesan yang disampaikan lewat media ada kalanya sebagai hiburan begitupun media sekarang lebih dominan dengan sajian hiburan, tetapi dengan bukti itu bisa kita kemas dalam sajian hiburan tersebut dengan kemasan nilai-nilai yang beredukasi.

Di tengah realitas menguatnya nuansa hiburan dalam ranah dakwah, tersisa harapan bahwa kampus sebagai langkah baru generasi dakwah mesti steril dari muatan bisnis, tetap terhalang tembok publikasi. Jadi nuansa idealitas dakwah di kampus tidak diakses publik selaku sasaran dakwah atau mad'u. Perkembangan pengkajian Islam di kampus atau melalui media dunia maya mencerminkan tingginya perhatian masyarakat terhadap dakwah untuk mengenal Islam secara fantastis. Hal ini menjadi akibat kemajuan teknologi, kini masyarakat memasuki era revolusi komunikasi ditandai dengan perubahan alatalat komunikasi berlangsung cepat. Tidak terkecuali pengaruh hiburan mewarnai kegiatan dakwah.

Derasnya arus informasi melalui media sulit dibendung. Dalam ruangan cukup sempit saja, mereka dapat mengakses informasi secara beragam, termasuk persoalan agama. Website yang menawarkan bacaan mencerahkan berjubel yang menyingkap khazanah dunia islam. Demikian aktivitas lesehan dakwah kaum muda dengan ghirah tadi melakukan jaringan- jaringan harakah. Implikasinya melahirkan polarisasi gerakan antara kelompok pengajian yang condong dogmatis dan kelompok pengkajian dengan mengusung berbagai isu-isu terkait wacana seputar Islam (Syobah 2013).

Kegiatan dakwah melalui jalur media diakui menjadi kebutuhan umat yang efektif dalam konteks hiburan tapi tidak melepaskan orientasi dakwah untuk menegakkan kebenaran dan mencegah berbagai bentuk kemunkaran, seperti penindasan dan kekerasan. Artinya, umat Islam saatnya harus sadar media atau peduli terhadap keberadaan media.

Dengan berkiprah sebuah pesan dakwah terhadap perkembangan zaman khususnya melalui media tersebut, lambat laun perkembangan dakwah akan berkembang dengan baik, tetap dengan kemasan-kemasan yang memiliki nilai islam dan beretika meski dalam media sangat rawan dengan penyampaian pesan hoax, tetapi dengan kita didasari Al-Qur'an dan Hadist pesan dakwah yang tersirat akan kuat tidak terombang ambing dengan marak hoax-nya media.

\subsection{Efek Media Massa}

Seluruh elemen yang berkaitan dengan media massa didasarkan pada asumsi bahwa media memiliki dampak, meskipun belum langsung diperoleh kesepakatan yang jelas mengenai dampak tersebut, apakah hal ini bersifat langsung atau tidak langsung memberi pengaruh yang besar atau kecil. Secara esensial, media massa telah memberi pengaruh kepada manusia baik secara langsung ataupun tidak langsung. Menurut McLuhan bentuk media saja memberi pengaruh kepada kita. Pengaruh yang ditimbulkan oleh sebuah 
medium bukan hanya terletak pada isi pesannya, melainkan pula dipengaruhi oleh jenis media komunikasi yang dipergunakan interpersonal, media cetak atau televisi (Rahmat 1999).

Sementara itu, Katz dalam Curran, et.al, pada kutipan jurnal Dawkah Tabligh karya Nurul Syobah, memberi tanggapan mengenai pengaruh media massa dalam dua model dominan yaitu: Pertama, irrational model of man yaitu pandangan yang menganggap orang-orang sebagai mangsa kekuatan sugesti yang bersumber dari pesan media. Kedua, mengacu pada pandangan rational model, dimana orang-orang dipandang sebagai sosok yang penuh perhitungan (calculative) dan selalu melakukan pendekatan rasional dalam menerima informasi baru. Meskipun demikian beberapa hal yang dipaparkan sebelumnya tetap dipengaruhi oleh pengalaman dasar seseorang, khususnya melalui apa yang disebut lingkup referensi (frame of reference) dari jenis dan jumlah pengalaman (field of experience) (Syobah 2013).

Dari berbagai uraian terdahulu, dapat dipahami bahwa ternyata audiens dalam menerima sebuah informasi tidak begitu saja menerimanya secara langsung, tetapi pesan yang diterima tersebut melewati beberapa tahap dalam proses selektivitas individu. Proses selektivitas ini tidak hanya dirangsang oleh informasi media, tetapi juga amat banyak dipengaruhi oleh faktor-faktor internal dan eksternal seorang individu. Demikian pula yang terjadi dalam proses pesan-pesan keagamaan melaui media massa. Media massa diyakini dapat memberi kesan khusus dan efek terhadap individu, kelompok atau lingkungan tertentu. Secara personal (individu) media massa dapat memberi pengaruh pada tiga level yaitu efek kognitif, afektif dan konasi.

\subsection{Orientasi (Tawjih) Pengembangan Dakwah}

Orientasi atau penggerakan dakwah merupakan inti dari manajemen dakwah, karena dalam proses ini semua aktivitas dakwah dilaksanakan. Dalam penggerakan dakwah ini, pimpinan menggerakan semua elemen organisasi untuk melakukan semua aktivitas-aktivitas dakwah yang telah direncanakan, dan dari sinilah aksi semua rencana dakwah akan terealisir sehingga orientasi dan gerak dakwah akan sesuai dengan harapan yang telah disusun.

Agar fungsi dari tawjih ini dapat berjalan secara optimal, maka harus menggunakan taknik-teknik tertentu yang meliputi: Pertama, memberikan penjelasan secara komprehensif kepada seluruh elemen dakwah yang ada dalam organisasi dakwah atau tatanan dakwah tersbut. Kedua, usahakan agar setiap pelaku dakwah menyadari, memahami, dan menerima baik tujuan yang telah diterpakan tersebut. Ketiga, Setiap pelaku dakwah mengerti kondisi dan keadaan objek dakwah.

Untuk itu peran da'i atau pimpinan dakwah akan sangat penting menentukan warna dari kegiatan-kegiatan sebagai bentuk pengembangan dakwah. Maka dari itu kegiatan-kegiatan dakwah akan terakomodir sampai pada sasaran yang telah ditentukan. 
Disamping itu ada beberapa poin dari proses orientasi pengembangan dakwah yang menjadi kunci pada kegiatan dakwah, diantaranya:

Pertama pemberian Motivasi, dalam hal ini motivasi merupakan dinamisator bagi para elemen dakwah dalam penunjang kegiatan dakwah, sehingga pesan yang akan disampaikan akan mudah diterima oleh mad'u jika dalam pesan dakwah tersebut terdapat pesan motivasi sebagai mengajak dalam menentukan perubahan terhadap dirinya.

Kedua Melakukan Bimbingan, dalam hal ini ialah nasihat untuk membantu para da'i dalam melaksanakan peran -perannya serta mengatasi permasalahan dan menjalankan tugasnya. Bimbingan yang dilakukan oleh pimpinan dakwah (da'i) terhadap pelaksanaan kegiatan dapat dilakukan dengan jalan memberikan perintah atau sebuah petunjuk serta usaha-usaha lain yang bersifat memengaruhi atau menetapkan arah tugas dan tindakan para da'i.

Ketiga penyelenggaraan komunikasi, yakni suatu proses yang digunakan oleh manusia dalam usaha untuk membagi arti lewat transmisi pesan simbolis merupakan hal yang sangat penting. Karena tanpa komunikasi yang efektif pola hubungan antara da'i dan mad'u nya akan mandek tidak saling memberi keuntungan. Dalam proses komunikasi ini akan terjadi sebuah proses yang melibatkan banyak orang yang mencoba memahami cara masing-masing manusia berkomunikasi. Dalam hal ini ketika komunikasi efektif berjalan antara da'i dan mad'u akan menghasilkan beberpa hal yang diharapkan diantaranya: (1) Komunikasi dapat menempatkan orang-orang pada tempat yang seharusnya. (2) komunikasi menempatkan orang-orang untuk terlibat pada forum lingkup tersebut. (3) komunikasi menghasilkan hubungan yang saling menguntungkan satu sama lain dalam memenuhi suatu kebutuhannya serta dapat menolong orang untuk mengerti perubahan (Munir dan Ilaihi 2006).

Sebagai bentuk transformasi, kemajuan ilmu pengetahuan dan teknologi zaman sekarang dapat mempengaruhi kegiatan dakwah yang dilakukan oleh para pelaku dakwah (da'i). Oleh karena itu, dakwah zaman sekarang sudah seharusnya dikemas dalam berbagai metode yang efektif sesuai dengan kondisi objeknya. Dakwah bil-lisan yang selama ini digunakan oleh para pelaku dakwah, sudah dianggap tidak bisa memadai lagi,. Oleh karena itu, dakwah seharusnya menggunakan metode-metode komunikasi sebagaimana halnya penyampaian informasi secara umum, ialah dengan menggunakan media komunikasi yang komunikatif. Diantaranya ialah dengan surat kabar dan televisi merupakan salah satu media massa yang banyak mendapatkan perhatian seluruh lapisan masyarakat. Namun media tersebut belum banyak dimanfaatkan dengan baik oleh para pelaku dakwah zaman sekarang ini disebabkan media massanya hanya bisa memandang sebelah mata hanya sebagai kebutuhan medianya sendiri pada masa seketika saja.

Untuk melihat secara jelas mengapa dakwah zaman sekarang ini perlu melalui media massa atau media sosial, maka perlu 
melihat beberapa unsur dakwah seperti yang tertulis dalam buku manajemen dakwah karya M. Munir dan Wahyu Ilaihi bahwa unsurunsur dakwah diantaranya: Da'i (pelaku dakwah), Mad'u (penerima dakwah), Maddah (materi dakwah), Wasilah (media dakwah), Thariqoh (metode dakwah), dan Atsar (efek dakwah) (Munir dan Ilaihi 2006). Unsur-unsur tersebut salah satu diantaranya adalah media dan sarana dakwah. Media dalam sebuah informasi adalah sangat penting, karena media merupakan saluran informasi yang merupakan faktor penentu berhasil tidaknya suatu pesan yang disampaikan oleh komunikator.

Realita membuktikan bahwa dakwah bil-lisan pada zaman sekarang ini tidak cukup hanya di masjid saja, orientasi yang dilakukan oleh pelaku dakwah atau da'i ialah bisa mentransformasikan keadaan serta objek dakwah pada kondisi seperti ini, yaitu dengan memanfaatkan teknologi melalui media massa dan media sosial diantaranya dengan mengkemas pesan dakwah tersebut degan bentuk video atau tulisan yang bias dimuat langsung ke media. Pesan dakwah dalam bentuk video bisa kita bagikan melalui akun instagram, youtube, facebook, twitter, whatsapp dan lain media yang bisa mendukung untuk menyampaikan pesan dakwah tersebut. Selanjutnya untuk pesan dakwah dalam bentuk tulisan bisa kita bagikan melalui halaman portal news online, blog, atau ke media cetak lainnya.

Sebagai bentuk alternatif pilihan media dakwah, dengan memperhatikan realitas objektif kemampuan pendanaan dan kemampuan pengelolaan media massa sebagai salah satu produk media telekomunikasi, berikut diantaranya: Pertama, juru dakwah perlu mengembangkan pengadaan media komunitas seperti, radio, TV dan media cetak yang memiliki kemampuan jangkauan terbatas di tingkat lokal. Pilihan media ini perlu, karena tiga media yang disebut di atas memiliki kedekatan dengan masyarakat dan memiliki tingkat efektifitas yang tinggi. Alasan lain pilihan media tersebut, didasarkan pada kemampuan umat Islam di bidang pendanaan. Pengadaan media komunitas ini secara finansial tidak membutuhkan pendanaan yang sangat besar.

Kedua, juru dakwah perlu dilengkapi dengan kemampuan di bidang pengelolaan media massa yang menjadi pilihan alternatif, apakah itu radio, TV atau media cetak, karena dengan adanya spesifikasi kemampuan di bidang pengelolaan media massa, juru dakwah dapat melakukan dakwah secara profesional. Dan Ketiga, penanganan dakwah secara profesional di media massa ini hendaknya dilakukan secara terpadu, baik sumber daya manusia yang terlibat dalam proses dakwah maupun pilihan pesan-pesan dakwah yang dituangkan pada media massa. Penerapan sistem dakwah secara terpadu ini, agar pelaksanaan dakwah di media massa bisa dilakukan sebaik mungkin, dan agar sasaran dakwah merasa tertarik dengan dakwah yang dilakukan. Kalau ini bisa diwujudkan, maka dakwah akan terlaksana secara efektif dan efisien (Ummatin 2008).

Harapan tersebut seirama dengan apa yang dinyatakan oleh Hasan Basri Tanjung pada kutipan jurnal Dakwah Tabligh karya 
Nurul Syobah bahwa beranjaknya kehidupan masyarakat pada tahap informasi telah mengajak kita untuk melangkah lebih jauh atau paling tidak sama dengan perubahan sosial yang ada. Untuk mengantisipasi hal tersebut kata beliau, dakwah bil-lisan tidak memadai lagi, tetapi harus mendapat dukungan dengan suatu media yang refresentatif dan relevan dengan cakrawala pikiran manusia yang semakin maju (Syobah 2013).

\section{Simpulan dan Saran}

\subsection{Simpulan}

$\begin{array}{rrr}\text { Berdasarkan } & \text { pemaparan diatas, } \\ \text { dakwah merupakan sesuatu yang } & \text { sangat }\end{array}$ penting bagi kelangsungan hidup umat manusia terutama dalam menyiarkan suatu ajaran dalam masyarakat. Ajaran yang baik tidak mustahil akan hilang apabila tidak didakwahkan dan sebaliknya ajaran yang sesat dapat tersiar dan membudaya dalam masyarakat jika didakwahkan secara berkesinambungan. Dengan aktivitas dakwah yang berkesinambungan maka akan mendorong kemaslahatan hidup manusia baik di dunia maupun di akhirat. Bahkan dakwah itu merupakan salah satu dari kewajibankewajiban besar yang harus dilaksanakan oleh umat Islam.

Sisi lain pada fungsi media massa untuk memberi informasi pada khalayak, tentunya sesuai dengan tujuan dakwah itu sendiri, di mana dakwah adalah bagian yang tidak terpisahkan dari pengalaman keislaman seseorang maka tindakan dakwah dapat dilakukan dengan berbagai cara dan media sepanjang hal tersebut tidak bertentangan dengan kaidah Islam. Namun demikian, karena sifat khusus tindakan dakwah, maka tindakan yang hanya berisikan tentang ajakan, seruan panggilan dan penyampaian pesan seseorang atau sekelompok orang sehingga orang lain dan masyarakat menjadi muslim yang dapat disebut sebagai tindakan dakwah dalam pengertian yang luas.

Pelaksanaan dakwah melalaui media sesungguhnya selaras perintah Islam yang mewajibkan sebagian dari umat Islam yang memiliki ilmu untuk berdakwah, terutama ketika seorang muslim melihat kemunkaran yang dilakukan secara terang-terangan. Dakwah bukan hanya sekadar kebaikan dan bukan pula untuk menambah jumlah kaum muslimin saja, akan tetapi hal itu dituntut justru untuk mewujudkan tanggung jawab misi umum diutusnya Nabi Muhammad saw di tangan umat Islam. Tanggung jawab ini merupakan tanggung jawab setiap individu umat Islam yang wajib ditunaikan, karena tanggung jawab risalah ini telah dibebankan Allah atas umat untuk disampaikan kepada umat manusia setelah Nabi Muhammad wafat. Jika umat Islam melalaikan kewajiban dakwah ini berarti telah melalaikan kewajiban risalah yang diwajibkan oleh Allah untuk dilaksanakan dan Allah mengharamkan kedudukan 'khaira ummatin' karena kedudukan itu hanya diberikan kepada umat yang melaksanakan risalah dakwah.

Beberapa poin dari proses orientasi pengembangan dakwah yang menjadi kunci pada kegiatan dakwah, diantaranya: Pertama pemberian motivasi, Kedua melakukan 
bimbingan, dan Ketiga penyelenggaraan komunikasi yang efektif.

Meskipun demikian, media menyadari bahwa dakwah merupakan kebutuhan masyarakat termasuk informasi atau pemberitaan soal agama. Dalam konteks ini media mengemasnya dalam bentuk model draf teks, foto maupun video yang mengandung pesan-pesan keagamaan yang diangkat dari peristiwa keagamaan sebagai orientasi pengembangan dakwah secara signifikan.

\subsection{Saran}

Berdasarkan hasil penelitian dan pembahasan mengenai orientasi pengembangan dakwah melalui sistem komunikasi (media massa) melalui pengamatan beberapa tokoh-tokoh dakwah atau tokoh masyarakat lainnya yang bergelut dalam dunia dakwah, baik dakwah secara langsung ataupun dakwah melalui media. Meski begitu ada beberapa masukan yang ingin penulis rekomendasikan:

1) Para pelaku dakwah harus lebih peka terhadap keadaan dan kondisi masyarakat atau dunia ini, supaya keadaannya bisa dikendalikan langsung oleh pedoman Al-Qur'an dan Hadits.

2) Seorang pelaku dakwah pada zaman sekarang ini harus cekatan dalam menggunakan media atau harus bersahabat baik dengan media apapun, supaya bisa selaras atau tercapai dengan tujuan awal dakwah.

3) Tetap berpegang teguh pada ajaran AlQur'an dan Hadits.

\section{Daftar Pustaka}

Ali, Abdullah. 2004. Antropologi Dakwah. Cirebon: KPI STAIN PRESS Cirebon.

Ardianto, Elvinaro, Lukita Komala, dan Siti Karlinah. 2012. Komunikasi Massa. Edisi Revi. Bandung: Simbiosa Rekatama Media.

Hefni, Harjani. 2015. Komunikasi Islam. Jakarta: PT. Fajar Interpratama Mandiri Kencana.

Hendra, Tomi, dan Siti Saputri. 2019. "Dinamika Dakwah Dalam Perspektif Komunikasi." Jurnal Hikmah 13 (2): 259-74. http://jurnal.iainpadangsidimpuan.ac.id/index.php/Hik/art icle/view/1974.

Ilaihi, Wahyu. 2013. Komunikasi Dakwah. Bandung: PT Remaja Rosdakarya.

Munir, Muhammad, dan Wahyu Ilaihi. 2006. Manajemen Dakwah. Cetakan 1. Jakarta: Kencana.

Patilima, Hamid. 2005. Metode Penelitian Kualitatif. Bandung: Alfabeta.

Sugiyono. 2018. Metodologi Penelitian Kualitatif. Bandung: Alfabeta.

Suisyanto. 2006. Pengantar Filsafat Dakwah. Yogyakarta: Teras.

Syamsuddin. 2016. Pengantar Sosiologi Dakwah. Jakarta: PT. Kharisma Putra Utama Kencana.

Syobah, Nurul. 2013. "Kontruksi Media Massa Dalam Pengembangan Dakwah." Jurnal Dakwah Tabligh 14 (2). http://journal.uinalauddin.ac.id/index.php/tabligh/article/v iew/324.

Ummatin, Khoiro. 2008. "Globalisasi Komunikasi Dan Tuntunan Dakwah Bermedia." Jurnal Dakwah Media Komunikasi Dan Dakwah 9 (2). http://ejournal.uinsuka.ac.id/dakwah/jurnaldakwah/article/v iew/441. 